\title{
The Coup de Grâce to the Sanders Campaign: Michigan, Momentum \& Viability
}

\author{
Dino P. Christenson ${ }^{1} \cdot$ Corwin D. Smidt ${ }^{2}$ \\ (C) Springer Science+Business Media, LLC, part of Springer Nature 2020
}

\begin{abstract}
We illuminate the dynamics of primary campaigns by looking at how individuals changed their candidate support, favorability and viability within a crucial state in the 2020 primary. Via a multi-wave survey of likely primary voters in Michigan, we show that Joe Biden's comeback win was due primarily to the change in perception of his viability following South Carolina and Super Tuesday, especially among the more moderate portion of the Democratic electorate. In subsequent county-level analyses we find that the difference between Bernie Sanders's win in 2016 and loss in 2020 was more a function of changes in the Democratic primary electorate than in his appeal. Our work suggests that gains in viability do not benefit all candidates equally. Moreover, viability can be generated later in the schedule than previously thought and to decisive ends. We consider the implications of our findings for understanding Michigan's outcome in November.
\end{abstract}

Keywords Presidential nomination campaigns $\cdot$ Viability $\cdot$ Favorability $\cdot$ Michigan primary $\cdot$ Biden $\cdot$ Sanders

Despite formally announcing his campaign for the 2020 Democratic nomination relatively late, Joe Biden was undoubtedly the national frontrunner since the invisible primary began. As former Vice President and a long-serving senator he had a national profile, a strong elite network, and thus was consistently at the head of national and key state polls throughout 2019. However, the start of 2020 would look quite different for him. Biden stumbled early, finishing fourth in Iowa's caucuses and fifth in the New Hampshire primary. Meanwhile, Bernie Sanders's virtual tie with Pete Buttigieg in Iowa and wins in New Hampshire and Nevada suggested promising momentum for the party outsider. The stage was set for a competitive race in the subsequent states.

Among the states thought to be determinative of the candidates' fates was Michigan, which held its primary March 10 .

Dino P. Christenson

dinopc@bu.edu

Corwin D. Smidt

smidtc@msu.edu

1 Department of Political Science, Boston University, 232 Bay State Rd, Boston, MA 02215, USA

2 Department of Political Science, Michigan State University, 303 S. Kedzie Hall, East Lansing, MI 48824, USA
Sanders, having surprisingly upset Hillary Clinton there four years earlier, seemed ready to do the same to Biden. Indeed, polls following his early victories in mid-February showed Sanders with a commanding 9-point lead among likely primary voters in Michigan. ${ }^{1}$ To many observers, this was hardly a surprise: his previous success in the state, particularly with young voters, and working-class message left him with a grassroots network already intact as well as high-profile endorsements, including Representative Rashida Tlaib (Gray 2020). Moreover, he had made more campaign visits and raised more money there than the rest of the field (Burke and LeBlanc 2020). With such a history and investment in the state, there were high expectations for Sanders, leading some pontificators to believe that a loss here would seal his fate (e.g., Cillizza 2020).

Biden, however, also had a strong history in the state and a number of important relationships of his own, illustrated by endorsements from the Mayor of Detroit, Mike Duggan, and former Governor James Blanchard (LeBlanc 2020). As vice president, he had visited the state a number of times, supporting federal grants for mass transit as well as the bailout for the automotive companies. More importantly, perhaps, Biden was coming off a sound victory in the South Carolina

\footnotetext{
${ }^{1}$ YouGov survey for University of Wisconsin https://elections.wisc.edu/first2020-election-survey/.
} 
primary in late February, catapulting him into Super Tuesday three days later, when he won 10 states.

Over the following week, Biden made a late comeback and trounced Sanders in Michigan, carrying 53 percent of the vote (to Sanders's 36 percent). He won 73 convention delegates there, while also taking smaller delegate prizes from victories in four other states on that day. The victory in Michigan resonated longer than usual this year. As the COVID-19 pandemic continued to spread in the United States, a national emergency was issued three days later, leading a number of subsequent states to delay their primaries. In-person audiences were ended for debates and other campaign events. The dynamics of the nomination campaign were irreversibly altered, effectively making Michigan the last big event of the primaries not overwhelmed by coronavirus.

What drove this change in fortune for the candidates in Michigan? How did Sanders go from winner in 2016 to loser in 2020? Though Biden was the clear frontrunner in 2019, both Sanders and Biden had victories and key endorsements in previous states, and each led at different times in national and state polls in advance of the state's primary. Did these polls reflect true changes in voter preferences over the course of the campaign? If so, was the change due to evolving perceptions of candidate characteristics, ideology or viability? Or were the polls merely underestimating support for Biden, perhaps due to missing subsets of likely primary voters? Beyond the knowledge we gain on nomination campaigns, answering these questions may shed light on Michigan's outcome in the general election.

We illuminate the dynamics of primary campaigns by looking at change in candidate support, favorability and viability in Michigan, a crucial state in the 2020 Democratic presidential nomination campaign and 2020 general election. We begin by exploring data from a multi-wave survey of likely primary voters in the state. Our individual-level analyses show that despite a number of key events that led to greater information about the candidates' backgrounds and platforms, Biden's win was due primarily to the change in perception of his viability following the results in South Carolina and Super Tuesday, especially among the more moderate portion of the Democratic electorate. We supplement these findings with county-level analyses. These data show that the difference between Sanders's win in 2016 and loss in 2020 was more a function of changes in the Democratic primary electorate than in Sanders's appeal.

\section{Unprecedented 2020}

In many ways an unprecedented campaign is a redundant phrase. All campaigns vary in terms of context and candidates. Yet even by these standards, the 2020 Democratic primary is a particularly interesting and challenging campaign to study for its novelty. Beyond the COVID-19 pandemic that early in the season severely disrupted both the schedule and format of campaign events, the field of candidates and the voting rules were also unique. First and foremost, a record 29 major candidates sought the nomination, eclipsing previous highs of 16 Democratic candidates in 1972 (similarly motivated by another unpopular Republican incumbent, Richard Nixon) as well as the Republican Party's 17 for the open seat in 2016. The crowded field suggested that Democrats were confident in their ability to challenge Donald Trump in the general election - or at least in the importance of doing so.

Second, the Democratic National Committee (DNC) reformed some of the primary process rules to enhance transparency and participation - not an uncommon practice since the McGovern- Fraser reforms (see, e.g., Polsby et al. 1983; Mayer 1996; Jewitt 2019). Most notably, following the uproar from Sanders supporters in 2016, the DNC reduced the role of unpledged delegates, also known as "superdelegates." The DNC did not eliminate the role of these party leaders unpledged to a candidate, but it prevented them from casting decisive votes on the first ballot in the event of a contested nomination. In addition, the DNC encouraged states to use primaries and make same-day or automatic registration available. Accordingly, nine states switched from forms of caucuses to primaries, leaving only three states and four territories with caucuses in 2020. While these reforms were meant to encourage participation, complications stemming from the coronavirus worked in the opposite direction. Moreover, there were a number of reasons to expect the nomination process to last longer than usual, including the last- minute backloading of primaries due to the pandemic, the potential for delegates to be dispersed among a crowded field, as well as the aforementioned reduction of control by party elites.

In 2020, Michigan was fortuitously positioned (for our purposes) in the middle of the primary calendar, but also right before the necessary rescheduling and disruptions brought about by coronavirus. While other states had their primaries that day, Michigan was the largest state with the greatest number of delegates. In addition, the race for the nomination was still competitive at this point. Entering the primary, Biden was leading in the delegate counts after a string of victories following South Carolina, but Sanders was still within striking distance. Since the other major candidates had dropped out, Michigan was effectively a two-candidate race.

\section{Changing Voter Preferences}

Primary campaigns remove a key heuristic of general elections from the voter's calculus, partisan- ship. Without clear partisan differences between the candidates, there is potential for less stability of vote choice throughout the campaign, not to mention across elections. Instead, explanations of vote 
choice in primaries have relied on candidate traits and qualities (Gopoian 1982; Marshall 1984; Norrander 1986), as well as issue positions (Bartels 1988; Aldrich and Michael Alvarez 1994) and ideology (Wattier 1983; Scala 2020). While these candidate factors are unlikely to change much during a campaign, information about them is not pervasive in nomination campaigns (Polsby and Wildavsky 2000), especially early on. Thus, voters may learn about candidates throughout the campaign and may adjust their vote accordingly.

Beyond candidate preference, the literature has also pointed to more strategic considerations of candidates in primaries. Bartels (1988) posits that voters consider a candidate's viability, either to support the winner (jumping on the bandwagon) or simply not to waste a vote. While a candidate's viability can change in an election as a result of any number of campaign events, scholarship on nomination elections has pointed to early primary contest results in particular (e.g., Bartels 1985; Popkin 1991; Abramson et al. 1992; Collingwood et al. 2012). The process is frequently described in terms of momentum ${ }^{2}$ : winning or beating expectations in early states gives a boost to a candidate's chances in subsequent states (see, e.g., Bartels 1988), ${ }^{3}$ a possibility given the sequential nature of primaries (Morton and Williams 2000).

Studies that have directly considered vote switching in primaries have been particularly attuned to these two sets of factors. For example, building on Stone et al. (1992) - who find that the interaction of candidate characteristics and perceptions of electability in the general ${ }^{4}$ contributed to candidate support in the 1984 Iowa Democratic caucuses - Collingwood et al. (2012) show that knowing about Obama's early state victories in 2008 affected perceptions of his viability, which in turn changed voters' preferences in his favor. Likewise, Kenney and Rice (1994) find central roles for momentum, viability and electability in vote switching to George H.W. Bush in 1988.

In the analyses that follow, we explore the factors that led Michigan primary voters to change their mind prior to casting a vote in 2020. Following earlier studies of nomination candidate preferences (e.g., Kenney and Rice 1994; Collingwood et al. 2012), we leverage multi-wave survey data to explain change as a function of candidate and voter characteristics as well as perceived viability following previous state results. We subsequently ask the related question of why Sanders was able to upset the frontrunner in 2016 in Michigan but not again in 2020. To that end, we compare county results in 2020 to those in 2016 to see what changed at the aggregate level for Sanders.

\footnotetext{
${ }^{2}$ Norrander (1996) provides a discussion of the different definitions and measures of momentum and related concepts.

${ }^{3}$ Though the findings of Mayer (1996) suggest that the effects of momentum may be exaggerated.

${ }^{4}$ The literature has even distinguished concerns over viability in the primary from electability in the general (Abramowitz 1989; Abramson et al. 1992; Mutz 1995). For instance, Abramowitz (1989) argues that viability affects vote choice through perceptions of electability.
}

\section{How Individuals Changed in 2020}

Our survey results come from a mail-to-web survey of Michigan registered voters, with sampling weights equal to their probability of voting. The survey was conducted over two waves with a brief email follow-up survey. The first wave ran from December through early January, representing Michigan voter attitudes before the Iowa caucuses. The sample size for this wave was 296, with 177 likely Democratic primary voters. The second wave was in the field from February 18 to March 3 (Super Tuesday), with 276 respondents and 169 likely Democratic primary voters. Most respondents ( 68 percent) took the Wave 2 survey before Biden's win in South Carolina and Super Tuesday.

\section{Wave 1: Biden Support Based on Viability}

There were not many public polls of Michigan before Iowa, but the handful that were conducted showed Biden with a close but consistent lead over Sanders. In Wave 1 of our poll, however, respondents were evenly split. Biden and Sanders each had the support of 25 percent of respondents, while the other half did not support either. But every indication is that Sanders's base of support was committed, whereas Biden's support was a function of his frontrunner status.

As Table 1 illustrates, among likely voters who recognized the two candidates, Sanders scored higher in favorability on our seven-point scale (5.14 vs. 4.67). Buttigieg, Amy Klobuchar, and Elizabeth Warren did not score as well as Sanders, but rated more favorable on average than Biden (of course, the group of voters who recognized these newer candidates was smaller). Over 60 percent of likely Democratic primary voters either rated a candidate as equally favorable or more favorable than Biden or Sanders in our survey, with not one respondent rating Biden highest in favorability, while 11 percent indicated they were most favorable towards Sanders.

How could it be that Biden was running equal or ahead of Sanders, despite Sanders being seen as more favorable? The simple answer is viability. Almost half of our sample (47.3 percent) of likely Democratic primary voters responded that they thought Biden was going to win the nomination, - a 37 point advantage over Sanders. Among likely voters who saw Biden as the likely winner, 34 percent supported him. In comparison, Biden was the first choice for only 5 percent of voters who did not see him as most viable. However, Sanders's support was less damaged by perceptions of viability. He was still the first choice among 20 percent of the likely Democratic primary voters who did not see him as the favorite to win the nomination.

Ideology plays a coordinating factor in the viability story. Biden's average favorability was relatively constant across likely Democratic primary voters that described themselves 
Table 1 Comparing Appeal of Biden and Sanders to Michigan Democratic Voters Across the Campaign

Time Frame

\begin{tabular}{lccc}
\hline & Pre-Iowa & Post-NH, Pre-SC & Post-SC, Super Tuesday \\
\hline \% Willing to Support & & & 54.5 \\
Biden & 47.6 & 20.6 & 55.8 \\
Sanders & 48.3 & 49.2 & 4.4 \\
Average Favorability Rating (4= Neutral, 7 = Very Favorable) & 4.2 & 4.5 \\
Biden & 4.7 & 4.4 & 43.1 \\
Sanders & 5.1 & & 38.2 \\
\% of Voters Seeing as Likely Winner & 47.3 & 7.2 & 47.5 \\
Biden & 10.6 & 4 & \\
Sanders & & & \\
\hline
\end{tabular}

Note: Percentages and averages calculated among respondents saying they intend to vote in the Democratic Presidential Primary. These are weighted by age and voter history to be proportional to the expected electorate.

as "liberal" or "extremely liberal" (mean of 4.7) and those that did not (mean 4.7). But Sanders's higher appeal was clearly a function of his ideology, as Democratic primary voters that described themselves as "liberal" or "extremely liberal" (an estimated third of the primary electorate) had a mean favorability rating for him at 6.2 (between favorable and very favorable), as opposed to only an average of 4.6 among those that did not identify as liberal. But non-liberal primary voters on average gave Sanders and Biden nearly equal favorability ratings. In summary, Biden's early strength in Michigan was most likely a function of his frontrunner status, whereas Sanders's appeal was concentrated among attached liberal voters.

\section{Wave 2: Sanders Fails to Gain from Viability}

Following the confusion of the delayed Iowa returns and Sanders's victories in New Hampshire and Nevada, Biden's ability to continue in the race depended on South Carolina. At that time, the few large sample public polls of Michigan showed Sanders leading a divided field by single digits, but not with more than 30 percent of the vote. ${ }^{5}$ Indeed, our own poll continued to show nearly half of likely primary voters in Michigan still willing to support Sanders, but these voters were becoming less favorable to each candidate. Both Biden and Sanders saw a decline in their average favorability ratings at this time, with Sanders showing a slightly larger drop (Table 1).

Sanders's decline is somewhat hard to fathom, since he was seen as the frontrunner among 47.5 percent of those same voters, a level essentially equal to Biden's status pre-Iowa. Why didn't Sanders's stronger viability broaden his appeal?

\footnotetext{
${ }^{5}$ YouGov survey for University of Wisconsin https://elections.wisc.edu/first2020-election-survey/.
}

One likely explanation is that the more moderate Democrats in Michigan became less supportive of his candidacy as his chances of winning the nomination grew. Indeed, Sanders's declining appeal to Michigan primary voters was largely a function of non-liberal Democratic voters becoming less favorable to his candidacy. The average rating among liberals and extreme liberals remained near 6 ("favorable"), as it was pre-Iowa, but the average among those more moderate dropped below a "neutral" rating to 3.8. So as Sanders became the strongest candidate in the field, he became less appealing to the estimated two-thirds of Michigan Democrats who did not identify as liberal or extremely liberal.

This divide in appeal had big consequences following Biden's South Carolina victory, his high- profile endorsements from Buttigieg, Klobuchar, and Mike Bloomberg, and his string of victories on Super Tuesday. Interestingly, these changes caused relatively little improvement among our respondents' average rating of Biden's favorability. But the larger group of moderate Democrats in the state were no longer split and became much more focused on Biden. He once again was being considered by over half the electorate and was now seen as slightly more likely to win the nomination than Sanders.

\section{What Changed from 2016?}

What was it about the Michigan Democratic primary that gave Sanders a surprise victory against the party favorite in 2016 but not in 2020? Our survey analysis suggests a majority of Democratic primary voters did not consider themselves liberal, and these voters were less supportive of Sanders. Biden was not the favorite among these non-liberal voters, but his renewed viability after South Carolina and Super Tuesday gave him greater gains in support. However, that profile of 
Fig. 1 Change in Sanders' Support by Michigan County Gains in Democratic Primary Voters. Note: Dots are sized proportional to each county's number of Democratic primary voters. Linear regression estimate weighted by county's relative size.

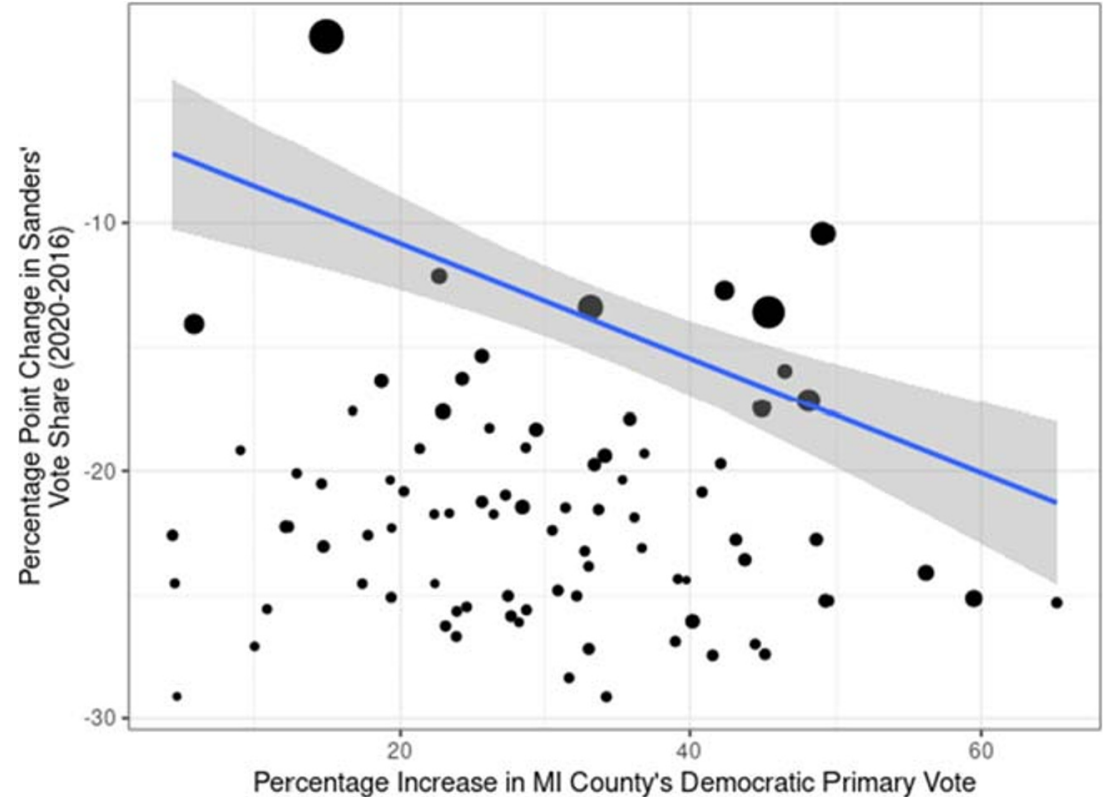

Biden's candidacy seemingly describes Clinton's status entering Michigan in 2016 as well. How did Biden come back to win in Michigan while Clinton did not?

A key difference between 2016 and 2020 was the sheer size of the electorate. The 2020 Michigan Democratic primary election had a much larger turnout (1.6 million) than that of 2016 (1.2 million). In 2016, Sanders received 598,943 votes to Clinton's 581,775 . In 2020, Sanders received only 22,000 fewer votes than in $2016(576,926)$, but that number was not nearly enough to win in 2020 because Biden received 840,360 votes.

When looking at county-level trends, we find a pattern consistent with Sanders failing to win new voters in 2020. Figure 1 plots the percentage-point change in Sanders's vote share by each county's percentage increase in Democratic primary voters; the dots are proportionately sized, and the regression trend line estimate is weighted according to the total number of 2020 Democratic voters in each county. Sanders's performance in 2020 was only slightly worse from 2016 in counties that saw small gains in turnout, especially in Michigan's most populous county, Wayne. But Sanders saw steep declines in support of 15 percentage points or more in counties that saw turnout increases above $40 \%$. Although these aggregate trends could be a function of other factors, they are consistent with the explanation that new voters in the 2020 Democratic primary made the electorate less liberal than the electorate that gave Sanders a victory in 2016.

Further county-level analyses support the interpretation that the larger Michigan Democratic primary electorate in 2020 was less liberal than the smaller one in 2016 - and less likely to support Sanders. Figure 2 once again plots the percentage-point change in Sanders's county vote share in 2020 compared to 2016, but this time as a function of each county's support for Trump in 2016. There is an exceptionally strong linear association between a county's support for Trump in 2016 and the change in Sanders's performance. Sanders's share of support dropped the most in counties that were most supportive of Trump. We have no evidence that the Democratic voters in these counties were less liberal, but it is clear that Biden received a greater portion of support than Clinton from Michigan Democrats who lived in purple (swing) and red (Republican-leaning) counties. Since Michigan has an open presidential primary and has its state party primary in August, and since the Republican nomination was not seriously contested, such an increase may simply be a function of avid voters in these less liberal counties choosing

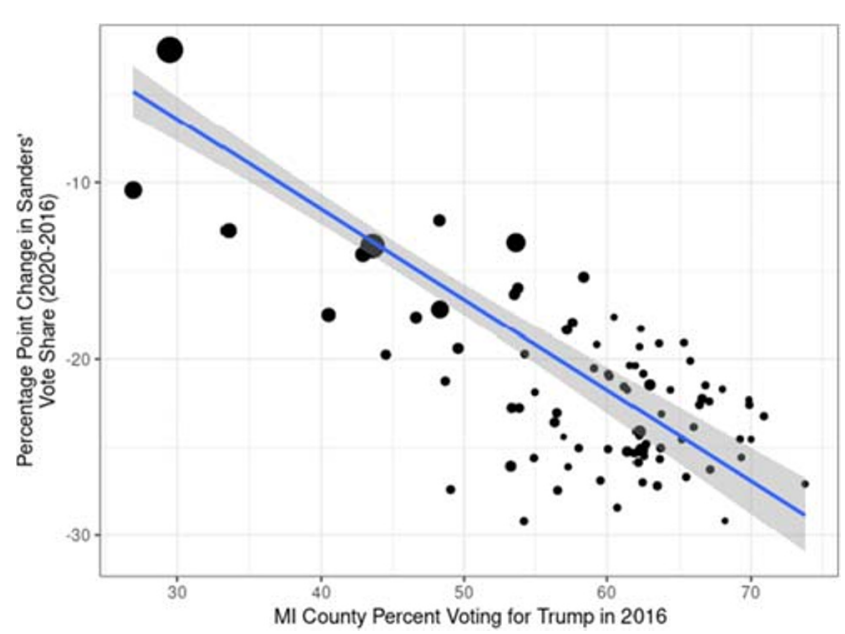

Fig. 2 Change in Sanders' Support by Michigan County Support for Trump in 2016. Note: Dots are sized proportional to each county's number of Democratic primary voters. Linear regression estimate weighted by county's relative size. 
to voice their support for frontrunner Biden over the more liberal Sanders.

In summary, the reasons why Sanders was able to beat the viable frontrunner Clinton in 2016 but not the viable frontrunner Biden in 2020 likely has little to do with each candidate's faults or strengths, and more to do with the expansion of the Michigan Democratic primary electorate between 2016 and 2020. Although Clinton may have had more negatives than Biden in 2016, Biden was still near the bottom of the 2020 field in terms of voter favorability. His support was clearly a function of viability and appeal across moderate and liberal Democrats. In contrast, Sanders's appeal to Michigan liberal voters was fairly consistent, but failed to expand to the more moderate portion of the electorate. Unfortunately for Sanders, this portion of the electorate became larger in the 2020 primary.

\section{Consequences for November and Beyond}

Our findings have clear implications for how we think about nomination campaigns. They may also enrich our expectations for Biden's general election performance against Trump in key Midwestern swing states such as Michigan.

In terms of nomination campaigns, 2020 demonstrates that viability was particularly important for Biden's candidacy, but much less so for Sanders. Although Sanders's lead in February was just as strong as Biden's prior to Iowa, the former's support failed to grow beyond the more liberal wing of the Democratic electorate. While we are limited to the 2020 campaign here, the results suggest that viability may be more of a unifying force for the party's moderate wing.

In addition, the swing in viability that benefited Biden came about surprisingly late in the 2020 primary campaign. Such a late change is particularly notable, given that much of the recent literature has pointed to factors prior to the start of the nomination contests as determinative of the nomination (e.g., Adkins and Dowdle 2005; Steger 2007; Cohen et al. 2008). Prior research has also pointed to performance in early states as generating momentum, sending cues to the rest of the country and contributing to overall candidate success in the primary (e.g., Mayer 1987; Bartels 1988; Polsby and Squire 1989; Abramowitz 1991; Redlawsk et al. 2011; Christenson and Smidt 2012). Our work suggests that, conditional on the candidate, viability can be generated later in the schedule than previously thought and to decisive ends.

In looking toward the general election and Michigan's role in it, we find that the Michigan Democratic primary electorate was larger and from more ideologically moderate areas in 2020 than in 2016. This change in composition made the state harder to win for the liberal Sanders, and more prone to unify around the frontrunner Biden in 2020 than the frontrunner Clinton in 2016. We fail to find evidence that Sanders lost ground among his base. Instead, Biden's win speaks more to changes in the electorate than to something specific about either candidate. Our survey evidence indicates Biden was a viability candidate, and that clearly played a more prominent role in 2020. Indeed, our finding that the expanded Democratic primary electorate was key to Biden's victory in Michigan suggests Democrats will have a strong chance to regain this former blue state in November.

Dino P. Christenson is an Associate Professor of Political Science at Boston University. Corwin D. Smidt is an Associate Professor of Political Science at Michigan State University.

Acknowledgments The authors' names are listed alphabetically. We thank Dante Scala for his support and insightful comments on this article as well as Jonathan Imber for his encouragement.

\section{Further Reading}

Abramowitz, Alan. 1989. "Viability, Electability, and Candidate Choice in a Presidential Primary Election: A Test of Competing Models." The Journal of Politics 51:977-992.

Abramowitz, Alan. 1991. "Incumbency, Campaign Spending, and the Decline of Competition in United-States House Elections." Journal of Politics 53:34-56.

Abramson, Paul R., John H. Aldrich, Phil Paulino and David W. Rohde. 1992. "'Sophisticated' Voting in the 1988 Presidential Primaries." American Political Science Review 86:55-69.

Adkins, Randall E and Andrew J Dowdle. 2005. "Do Early Birds Get the Worm? Improving Timeliness of Presidential Nomination Forecasts." Presidential Studies Quarterly 35(4):646-660.

Aldrich, John H and R Michael Alvarez. 1994. "Issues and the presidential primary voter." Political Behavior 16(3):289-317.

Bartels, Larry M. 1985. "Expectations and preferences in presidential nominating campaigns." The American Political Science Review 804-815.

Bartels, Larry M. 1988. Presidential Primaries and the Dynamics of Public Choice. Princeton, NJ: Princeton University Press.

Burke, Melissa Nann and Beth LeBlanc. 2020. "Poll: Biden leads Sanders in Michigan ahead of Democratic primary." The Detroit News. March 3. https:/www.detroitnews.com/story/news/politics/ 2020/03/04/ poll-biden-leads-sanders-michigan-ahead-democraticprimary/4942959002/.

Christenson, Dino P. and Corwin D. Smidt. 2012. "Still Part of the Conversation: Iowa and New Hampshire's Say within the Invisible Primary." Presidential Studies Quarterly 42(3):597-621.

Cillizza, Chris. 2020. "If Biden wins Michigan, is it all over?" CNN . March 10. cnn.com/2020/03/09/politics/joe-biden-michigan-2020bernie-sanders/index.html.

Cohen, Marty, David Karol, Hans Noel and John Zaller. 2008. Beating Reform: Political Parties and Presidential Nominations Before and After Reform. Chicago: University of Chicago Press.

Collingwood, Loren, Matt A Barreto and Todd Donovan. 2012. "Early primaries, viability and changing preferences for presidential candidates." Presidential Studies Quarterly 42(2):231-255.

Gopoian, J David. 1982. "Issue preferences and candidate choice in presidential primaries." American Journal of Political Science pp. 523546.

Gray, Kathleen. 2020. "27 Michigan leaders, organizations have made presidential picks: Who they're endorsing." Detroit Free Press. 
March 6. https://www.freep.com/story/news/politics/elections/ 2020/03/06/ michigan-primary-presidential-endorsement-joebiden-bernie-sanders/4957661002/.

Jewitt, C.E. 2019. The Primary Rules: Parties, Voters, and Presidential Nominations. University of Michigan Press.

Kenney, Patrick J and Tom W Rice. 1994. "The psychology of political momentum.” Political Research Quarterly 47(4):923-938.

LeBlanc, Beth. 2020. "Michigan tests Biden's electability as experts say black voters need rallying." The Detroit News . March 2. https:// www.detroitnews.com/story/news/politics/2020/03/ 02/michigantests-biden-electability-experts-rally-black-voters/4857597002/.

Marshall, Thomas R. 1984. "Issues, personalities, and presidential primary voters." Social Science Quarterly 65(3):750.

Mayer, W.G. 1996. The Divided Democrats: Ideological Unity, Party Reform, And Presidential Elections. Transforming American Politics Avalon Publishing.

Mayer, William G. 1987. "The New Hampshire primary: A historical overview." Media and momentum: The New Hampshire primary and nomination politics 9:20.

Morton, Rebecca B and Kenneth C Williams. 2000. Learning by voting: Sequential choices in presidential primaries and other elections. University of Michigan Press.

Mutz, Diana C. 1995. "Effects of Horse-Race Coverage on Campaign Coffers: Strategic Contributing in Presidential Primaries." Journal of Politics 57:1015-1042.

Norrander, Barbara. 1986. "Correlates of Vote Choice in the 1980 Presidential Primaries." Journal of Politics 48(1):156-166.

Norrander, Barbara. 1996. "Presidential Nomination Politics in the PostReform Era.” Political Research Quarterly 49(4):875-915.
Polsby, Nelson and Peverill Squire. 1989. "The Iowa Caucuses in a Front-Loaded System." The Iowa Caucuses and the Presidential Nomination Process pp. 149-62.

Polsby, Nelson W et al. 1983. Consequences of party reform. Oxford University Press.

Polsby, N.W. and A.B. Wildavsky. 2000. Presidential Elections: Strategies and Structures of American Politics. Presidential Elections Chatham House Publishers.

Popkin, Samuel L. 1991. The Reasoning Voter: Communication and Persuasion in Presidential Campaigns. Chicago: University of Chicago Press.

Redlawsk, DC, C.J. Tolbert and T. Donovan. 2011. Why Iowa? How Caucuses and Sequential Elections Improve the Presidential Nominating Process. Chicago, IL: University of Chicago Press.

Scala, Dante J. 2020. "The Skeptical Faithful: How Trump Gained Momentum among Evangelicals." Presidential Studies Quarterly .

Steger, Wayne P. 2007. "Who Wins Nominations and Why? An Updated Forecast of the Presidential Primary Vote." Political Research Quarterly 60(1):91-99.

Stone, Walter J, Ronald B Rapoport and Alan I Abramowitz. 1992. "Candidate support in presidential nomination campaigns: The case of Iowa in 1984." The Journal of Politics 54(4):1074-1097.

Wattier, Mark J. 1983. "Ideological voting in 1980 Republican presidential primaries." The Journal of Politics 45(4):1016-1026.

Publisher's Note Springer Nature remains neutral with regard to jurisdictional claims in published maps and institutional affiliations. 